Discussion Paper No. 636

INCOME UNCERTAINTY AND

SELF-REPORTED PRECAUTIONARY WEALTH:

EVIDENCE FROM THE JAPANESE MICRO DATA

Wako Watanabe

May 2005

The Institute of Social and Economic Research

Osaka University

6-1 Mihogaoka, Ibaraki, Osaka 567-0047, Japan 


\title{
Income Uncertainty and Self-Reported Precautionary Wealth: Evidence from the Japanese Micro Data
}

\author{
Wako Watanabe*
}

May 2005

\begin{abstract}
Using unique survey data which includes information on precautionary wealth and its target, we analyze the precautionary saving behavior of Japanese households. Our findings are: 1. Measures for income uncertainty have a positive influence on the target for precautionary wealth but not on precautionary wealth. 2 . The positive influence of income uncertainty on the target vanishes when older households with a head aged 51 or older are included in the sample. These findings suggest that Japanese households save against income uncertainty until around when their head is aged 50 and then save against other risks such as the longevity risk.
\end{abstract}

\footnotetext{
* I am indebted to Charles Yuji Horioka for many discussions and suggestions. I also thank for Naohito Abe and Ryuichi Tanaka for helpful discussions.

${ }^{\dagger}$ Institute of Social and Economic Research, 6-1 Mihogaoka, Ibaraki, Osaka 567-0047, Japan Tel: 81-6-6879-8686; FAX: 81-6-6878-2766

Email: watanabe@iser.osaka-u.ac.jp
} 


\section{Introduction}

We are exposed to various sources of risks in our economic life. Among them income uncertainty is the risk that most affects an individual's welfare through its influence on consumption. For an average family, the labor incomes of employed family members are the largest part of the household income as returns on financial assets and other non-labor incomes such as earnings from rented lands and homes are negligible. Hence, unexpected adverse shocks to labor incomes of working family members can have devastating impacts on the household's subsistence.

How do households cope with labor income risks? Apart from partial coverage of unemployment risks by public unemployment benefits, insurances, public or private, do not generally protect households from such labor income risks of salaried workers as pay and bonus cuts. Insurances aimed at volatile sales of the self-employed are almost nonexistent.

An individual (or a household) may self-insure against unanticipated adverse events in the future. Buffering motives for savings against future uncertainties are summarized as a precautionary motive for saving and are distinguished from savings for specified expenditures at various life stages such as purchasing durable goods, funding her children's schooling, a down payment for a home purchase, and the individual's living expenses after her retirement,.

In the following analysis, we run a regression of the precautionary wealth reported by the survey respondents on measures for household labor income uncertainties. If individuals save not only for specified future expenditures but also against uncertainties, individuals with a greater risk exposure should compress consumption and accumulates wealth more than those with a smaller risk exposure. 
A measure for income uncertainty should be more strongly (positively) correlated to self-reported precautionary wealth than (positively) to total household wealth or (negatively) to consumption. Individuals who face imminent income uncertainty not only reduce present consumption but may also give up some future consumption and reduce current savings for specified future expenditures. If such reallocation of savings is widely practiced, higher risk exposures do not affect total wealth and present consumption as much as the self-reported precautionary wealth.

We also use the target for precautionary wealth reported by survey respondents as another dependent variable. According to the buffer stock saving hypothesis proposed by Carroll (1992, 1997), an individual saves primarily against her risk exposure when she is young and less aware of her retirement. Carroll derives that a consumer engaged in a dynamic saving/consumption decision has her own target as a buffer against her risk exposure. The target for precautionary wealth depends on the consumer's preference and her risk exposure. Use of the self-reported target serves as a direct empirical test of the Carroll's hypothesis. Recently, Kennickell and Lusardi (2004) emphasized the importance using the self-reported wealth targets collected in the Survey of Consumer Finances in testing the precautionary saving hypothesis.

We group households into distinct homogeneous groups according to household occupational and demographic characteristics and calculate a measure for household labor income uncertainty as in Dardanoni (1991) and Zhou (2003). For instance, the business income of a self-employed is less stable than the salary of a worker of a large company under a longer-term contract. Such heterogeneity of income uncertainty across individuals is captured by varied risk exposures across groups of similar households. The logarithm of household labor income, the measure used in our analysis turns out to be empirically 
more plausible than the variance used by Dardanoni (1991) and Zhou (2003). When running regressions instrumental variables are used in order to remove a potentially serious simultaneity bias caused by a household's occupational choice.

A dummy variable indicating whether a household head is healthy or unhealthy is employed as an additional measure for income uncertainty. This variable is meant to capture the risk that a household head will go through a substantial period without labor income due to a sick leave or a job loss caused by deteriorated health conditions.

The data we use are taken from the Survey on the Financial Asset Choice of Households (SFACH) conducted by the Institute for Posts and Telecommunications Policy (IPTP) of the Ministry of Posts and Telecommunications of the Government of Japan (the present Japan Post Corporation).

What makes the SFACH unique is the survey on the household's current financial wealth and the household's wealth target for at least twelve saving motives in addition to the survey on total financial assets, borrowing, and various financial and demographic variables. Among twelve motives surveyed, "for peace of mind but not for specific reasons" best represents the saving for unanticipated income fluctuations. Another surveyed motive, "for illness, natural disasters, and other unexpected expenditures", captures the precautionary saving motive for uninsured and unanticipated expenses. The precautionary saving motive for uninsured unanticipated expenses is beyond the scope of this paper. ${ }^{1}$

Our main findings are: 1. Measures for income uncertainty have a positive influence on the self-reported target for precautionary wealth but not on precautionary wealth itself in younger households. 2 . The positive influence of income uncertainty on the self-reported

\footnotetext{
${ }^{1}$ For an empirical analysis of this type of precautionary saving, see Palumbo (1999).
} 
target for precautionary wealth vanishes for the sample including older households with a head aged 51 or older. These findings suggest that Japanese households save against income uncertainty until around when their head is aged 50 and then save against other risks such as the longevity risk afterward.

The paper is organized as follows. In section 2, the relevant literature is reviewed. In section 3, the data and econometric issues are examined. In section 4, the empirical results are reported. Section 5 concludes.

\section{Literature Review}

We will review the literature on precautionary saving in this section. ${ }^{2}$

Carroll $(1992,1997)$ formally modeled the individual's precautionary saving behavior. Assuming the forward looking individual's maximization of the more realistic utility function than the one assumed by the stripped-down life cycle model, he claimed that an ordinary individual starts to save for her retirement only in her early 50's and that she saves primarily for income uncertainty in the near future until then. In her youth when her saving motive is precautionary against uncertainties, the individual saves only as much as her target derived from her risk exposure and preference, which serves as a buffer against adverse realizations of her risk exposure. Carroll's buffer stock saving hypothesis successfully explains the stylized fact that consumption tracks income in the individual's earlier life. This had remained a puzzle under the stripped-down life cycle hypothesis according to which consumption is smoothed out over the individual's life and is independent of the concurrent level of income.

Results of empirical tests on the precautionary saving hypothesis are mixed. The

\footnotetext{
${ }^{2}$ See Browning and Lusardi (1996) and Murata (2003) for a more detailed literature review of the empirical research on precautionary saving.
} 
typical regression equation testing the hypothesis has consumption, flow saving, or wealth as a dependent variable and some income risk measure as an independent variable. Precautionary saving motive is said to exist if, controlling for demographic characteristics and life cycle saving for retirement, the employed income risk measure is negatively related to consumption, positively to saving, and positively to wealth.

There have been plenty of empirical works on precautionary saving motives using data from the US and Europe where micro household level survey data have been publicly available. Different variables are used as a measure for income risk. Such income risk measures used in the literature include occupation (Skinner [1988]), some measure for a labor income risk such as a variance (Carroll [1994], Carroll and Samwick [1997, 1998]), some measure for a risk of consumption growth (Dynan [1993]), an estimated probability of job loss (Carroll, Dynan and Krane [2003]) and some subjective measure of income risks reported by a survey respondent (Lusardi [1998]).

On the other hand, it is only recently that empirical investigation on precautionary saving began with the Japanese micro household level data. With the 1994 wave of the SFACH, Horioka and Watanabe (1997) find that 14 percent of the gross household flow of savings in financial assets is for a "peace of mind" motive. Using the 1996 wave of the same survey, Zhou (2003) group households in more homogeneous subgroups of households based on the household head's age group, occupation, and educational attainment. She then calculates the group variances of household labor income, and find that household consumption is lower for those who belong to a group with a higher group variance of labor income. Murata (2003) uses the yearly panel of the Japanese Panel Survey of Consumers from 1993 through 1998, and shows that a subjective measure for income uncertainty based on the respondent's self-report does not account for their 
financial wealth.

Studies on household level data from the US, Europe and Japan differ considerably in the importance of the precautionary saving motive to insure against income uncertainty. Some studies find a statistically significant coefficient on an employed income risk measure and others do not.

\section{Data and Empirical Methodology}

\subsection{Data}

The Survey on the Financial Asset Choice of Households has been conducted every two years since 1988. The most recent 9th wave of the SFACH was conducted in 2004. The sample of households of each wave is selected through a two-stage stratified sampling method. In conducting the survey, interviewers visit the selected sample households and asked them to fill out the questionnaire, and several days later, interviewers revisit them and collect the questionnaire. Similar questions were asked repeatedly but they were not necessarily identical across waves.

In this paper, the data from four waves of the SFACH, the 1994 wave (the fourth wave), the 1996 wave (the fifth wave), the 1998 wave (the sixth wave), and the 2000 wave (the seventh wave) are pooled and analyzed. For every wave used in our study, 6000 households including single-person households were surveyed and the response rate was over 60 percent $(65.4 \%$ in $1994,61.6 \%$ in $1996,62.6 \%$ in 1998 and $62.1 \%$ in 2000$)$. Every wave but the 2000 wave was conducted between the late November and the early December of the survey year, and the remaining 2000 wave was conducted between the late January and the early February of $2001 .^{3}$

\footnotetext{
${ }^{3}$ Examining the 1994 wave, Horioka and Watanabe (1997) ensure reliability of the SFACH, based on its comparison with the Family Saving Survey, the most widely used saving survey in Japan.
} 
In constructing the pooled data set of four waves of the SFACH, households with a head aged 29 or younger or households with a head aged 60 or older are dropped so that the study focuses on households whose head is of a working age. ${ }^{4}$ Single-person households are dropped since they are underrepresented in the SFACH. Households whose before-tax non-capital income is zero or missing are dropped. ${ }^{5,6}$ In addition, households with a female head, a head who is not working, who is working part-time, and who is a student, are dropped. $^{7}$

Dropping further households whose relevant demographic information such as the number of children and the age of the household head, the constructed sample pooling four waves of the SFACH includes 3903 households.

\subsection{Estimation of labor income uncertainty}

In this study, following Dardanoni (1991) and Zhou (2003), the measure for household

\footnotetext{
${ }^{4}$ The primary age of retirement in Japan is 60 . Households with a head in her 20's are dropped since many such households are yet to enter the workforce.

${ }^{5}$ We use after-tax income for our analysis, since data on before-tax income are not available for 1998 and 2000 waves of the SFACH.

${ }^{6}$ In the earlier two waves (1994 and 1996 waves), the survey collects information on whether individual household members such as a household head and his spouse have any capital income and if so how much. In the later two waves (1998 and 2000 waves), the survey collects information on whether an entire household has any capital income and if so how much. In calculating non-capital income, if households answer that they have capital income but do not answer the amount of capital income, we regard their capital income to be zero. Such way of processing the data is less likely to lead to underestimation of capital income because 1) only a fraction of households say they have capital income but do not report the amount of capital income (13 percent of household heads in 1994, 24 percent of household heads in 1996, 15 percent of households in 1998, and 7 percent of households in 2000), and 2) those who say they have capital income but who do not report the amount of capital income are likely to have little capital income compared to those who report the amount of capital income.

7 There are very few households with a female head in the SFACH data.
} 
labor income uncertainty is calculated for each group of homogeneous households sharing the same demographic characteristics. More precisely, following the grouping of households employed by Zhou (2003) in spirit but improving on it, the sample is grouped by the age group, cohort, occupation, and educational attainment of the household head.

Each age group and cohort considered have a 10 year window based on a household head's age and his cohort: i.e., 30's, 40's, 50's for age groups, and those born in the period from 1931 to 1940, in the period from 1941 to 1950 , in the period from 1951 to 1960 , and in the period from 1961 to 1970 . Occupations considered are employment in a private entity that employs less than 30 persons, employment in a private entity that employs 30 or more but less than 500 persons, employment in a private entity that employs 500 persons or more, public service, and self-employment that includes farming, forestry, and fishery. Educational attainments considered are junior high school, high school, and advanced education (junior college, college, or graduate school). ${ }^{8}$

As we emphasized in the previous section, using of the appropriate measure of (labor) income uncertainty is crucial in our empirical analysis. Table 1 presents the variance of and the standard error of the logarithm of after tax non-asset household income. The variance of the after tax total household non-capital income is higher for households whose heads are employed in medium sized (entities that employ 30 or more but less than 500 persons) and large private entities (entities that employ 500 or more persons) than for those whose heads are public servants. This is contradictory to common sense with regard to the stability of earnings for each of the three occupations.

Zhou (2003) uses the variance of the level of household labor income as a measure for labor income uncertainty for the regression of household consumption, and finds that the

${ }^{8}$ Zhou (2003) does not consider a cohort effect in grouping households since she uses only the 1996 wave. 
coefficient of this risk measure is negative and statistically significant, and thereby claims that precautionary saving motives exist in Japan. Her finding may be due to the fact that her income risk measure does not appropriately reflect the actual household labor income uncertainty.

The variance of the logarithm of total non-asset household income is larger for those employed in large and medium sized private entities than public servants. The standard intertemporal optimization model on consumption assumes that shocks (persistent or transitory) are specified as multiplicative shocks to the predictable component of labor income and hence they enter additively in the equation for the logarithm of the labor income process (see Hubbard, Skinner and Zeldes [1995], Carroll [1992, 1997], Gourinchas and Parker [2002]).

In this paper, following Carroll and Samwick ([1997], [1998]), we employ the logarithm of the variance of the logarithm of non-asset income, what Carroll and Samwick (1997, 1998) call LVARLY, as a measure for labor income uncertainty. In calculating LVARLY for the groups of households considered, groups with less than ten households are dropped for fear of inaccurate estimates of variances for these groups.

We employ an indicator (dummy) variable that takes the value of 1 if a respondent answers that the head of her household is healthy as an additional measure for household income risk. This variable is meant to capture the risk that a household will go through a period of little or no income. A household head with health related problems is more likely to leave his job and to lose income or is forced to take a sick leave and to go through a period of a substantial fall in his income than a healthy household head is. ${ }^{9}$

\footnotetext{
9 Ideally if the data collected information on previous occupations of a household head who is currently not working, we would be able to estimate the job loss risk in addition to earning uncertainty of the employed worker.
} 


\subsection{Questions on precautionary saving motives}

The SFACH surveys not only amounts of total financial assets held and total debts owed but also collects information on at least 12 saving motives such as "for one's children's educational expenses" and "for living expenses during retirement" in the four waves used for our analysis. ${ }^{10}$ Two of the motives are consistent with precautionary saving motives in a broader definition. The two such motives are "for illness, disasters, and other foreseen expenditures" and "no specific motive but for peace of mind" (hereafter "the peace of mind motive"). While the former is the precautionary saving motive for unexpected expenses and is not the focus of this paper, the latter is the most consistent with the theoretical concept of precautionary saving for income uncertainty. Since this is the only saving motive for unspecified expenses at present and in the future, any household that has precautionary wealth for income uncertainty should choose "the peace of mind motive" as one of its saving motives. "The peace of mind motive" is not listed as one of the surveyed borrowing motives, as households are unlikely to borrow for no specific expenses.

Use of saving for the peace of mind motive rather than a more broad measure for saving such as total wealth is important. Since saving for the peace of mind motive does not include saving for life cycle related motives, which are dealt with separately in at least 9 listed motives in the SFACH, the effect of the measure of income uncertainty on saving for the peace of mind motive should be stronger than that on other traditionally used

${ }^{10}$ The 12 saving motives surveyed in all four waves of the SFACH are, (1) for living expenses during retirement, (2) for illness, disasters, and other unforeseen expenditures, (3) for one's children's educational expenses, (4) for one's children's marriage expenses, (5) for the acquisition (including rebuilding and replacement purchase) of owner-occupied housing (including land), (6) for purchase of consumer durables, (7) for leisure expenses, (8) for the payment of taxes, (9) for an independent business, (10) no specific motive but for peace of mind, (11) in order to leave a bequest, and (12) other. 
dependent variables. The empirical results using total financial wealth which give unfavorable results for the precautionary saving hypothesis do not necessarily reject the precautionary saving hypothesis if the results with saving for the peace of mind motive support the hypothesis. ${ }^{11}$

The survey questionnaire is structured such that a respondent is first asked to answer whether her household has currently savings for each motive, and then the household's current financial wealth for that motive, the household's wealth target for that motive, and the number of years the household thinks it will need to meet that target. ${ }^{12}$

\subsection{The empirical model}

The main empirical model in this study is the same as the model analyzed by Lusardi (1998), Carroll and Samwick (1997, 1998), and Murata (2003) in structure, but the dependent variable is the logarithm of precautionary wealth, PEACE.

$$
\ln P E A C E_{i t}=\alpha_{0}+\alpha_{\sigma} L V A R L Y_{i t}+\alpha_{h} H_{i t}+\alpha_{y} \ln P_{i t}+X_{i t} \beta_{i t}+u_{i t}
$$

$H_{i t}$ is a dummy variable that takes on the value of 1 if the respondent answers that the household head is healthy and zero otherwise (hereafter "the health dummy"). $\quad P_{i t}$ is the estimated after-tax permanent income excluding returns on assets. $X_{i t}$ contains age and

\footnotetext{
${ }^{11}$ Specifying a functional form of a utility function, Parker and Preston (2002) decompose consumption growth into the negative effect of precautionary saving and the rest, and regresses the estimated negative effect of precautionary saving on consumption on income uncertainty.

${ }^{12}$ In the 1998 and 2000 waves of the SFACH, respondents are asked to report the proportion of the current financial wealth for the peace of mind motive to total financial wealth rather than the current financial wealth for that motive itself. Thus, in these two waves, the current financial wealth for the peace of mind motive is obtained by multiplying this proportion by the total financial wealth for each household.
} 
other demographic variables to control for the predictable life cycle effects on wealth. Variables included in $X_{i t}$ are the age of the household head, the square of the age of the head, the age of the head in 1990 as a cohort effect, the number of children in the household, and time dummy variables. ${ }^{13} u_{i t}$ is an error term. The measure for income uncertainty, $L V A R L Y_{i t}$, is supposed to be measured with an error.

Two variables are tested for PEACE, the household's current financial wealth for the peace of mind motive, PEACE_CURRENT and the household's wealth target for this motive, PEACE_TARGET. For households that answer they do not have savings for the peace of mind motive, missing values for PEACE_CURRENT and PEACE_TARGET are replaced with the value zero, but households that answer they have savings for the peace of mind motive and leave PEACE_CURRENT or PEACE_TARGET unanswered are dropped from the sample when the corresponding variable is used as a dependent variable. Such a treatment of missing values leaves households without the precautionary saving motive overrepresented in the sample. However, as long as the underlying structural model characterizing the precautionary saving behavior is unaltered no matter whether a dependent variable is positive or zero, which is our model specification described in the next subsection, and households are not dropped non-randomly, such overrepresentation of households with a dependent variable being zero does not bias the estimates.

\subsection{Endogeneity of the measure for income risk and use of instrumental variables}

Endogeneity of the measure for income risk LVARLY would bias its estimated coefficient. The error in the measure for labor income risk LVARLY could be large since it is not a directly observable variable but an estimated one.

${ }^{13}$ We followed Carroll and Samwick $(1997,1998)$ in selecting variables included in $X_{i t}$. 
Even more serious is likely the reverse causality from the individual's saving behavior to her income risk through her risk averseness that would result in underestimating the coefficient of LVARLY if an OLS regression were run. Risk-averse individuals save more precautionary wealth for income risks, and are also likely to choose a more stable occupation such as the public service or larger companies. On the other hand, risk loving individuals save less precautionary wealth, and are likely to choose unstable occupations such as self-employment or smaller venture companies where chances and opportunities may be plenty but risks are higher. Thus, (labor) income uncertainty and saving can be negatively related through an individual's risk-averseness.

In order to correct the bias on the estimate of the coefficient of LVARLY, we estimate the equation using an instrumental variable regression. As instrumental variables, we use exogenous variables in the equation to be estimated (the health dummy $\mathrm{H}$, and the variables included in X), dummy variables for regions (regional dummies), dummy variables for city size (city size dummies), dummy variables for educational attainment (education dummies, the base group being advanced degree holders), the square of the age of the head in 1990 (the square of the cohort effect), age interacted with education dummies, age squared interacted with education dummies, age interacted with a health dummy, age squared interacted with a health dummy, a cohort effect interacted with education dummies, and a cohort effect squared interacted with education dummies. We do not include dummy variables indicating the occupation of the household head, since the occupation of the household head is likely correlated with savings through risk averseness of family members in a household.

Indeed estimating the equation with instrumental variables is equivalent to a two-step estimation by running an OLS regression with predicted values of independent variables 
obtained through regressing them on instrumental variables. Thus, the value of $\ln P_{i t}$ predicted by instrumental variables is used in running the regression for precautionary saving. This is equivalent to saying that the permanent non-asset income estimated using age, education, the health condition, and the cohort effect of the household head, is used as an independent variable.

\section{Results}

\subsection{Descriptive Statistics and Preliminary Analysis}

Figure 1 displays the profiles of gross financial wealth, net financial wealth (gross financial wealth less debts), current financial wealth for the peace of mind motive and the share of current financial wealth for the peace of mind motive within gross financial wealth by the age group of the household head controlling for the birth year of the household head. As the household head ages, gross and net financial wealth increase monotonically, implying that households are accumulating financial wealth for their retirement as the life cycle hypothesis suggests. The savings for the peace of mind motive, on the other hand, do not increase as the household head ages.

As a result, the share of precautionary wealth within the household financial wealth remains high and ranges from 20 percent to 30 percent before 55, but declines to about 15 percent afterward. This feature of the age profile of our direct measure for precautionary wealth is consistent with the finding by Cagetti (2003), who simulates the share of liquid wealth attributable to a buffer against income uncertainty based on the estimates of preference parameters of a dynamic optimizing household using the wealth data on American households in the Survey of Consumer Finances. ${ }^{14}$

${ }^{14}$ Parker and Gourinchas (2002) and Abe and Yamada (2005) estimate preference parameters using consumption data on American and Japanese households respectively and conduct a similar simulation 
Descriptive statistics of dependent variables and independent variables are presented in Table 2. In the following analysis, for the baseline regressions, households with a head aged 50 or younger are selected in the sample as in Carroll and Samwick $(1997,1998)$. This is intended to exclude from the sample life cycle savers who primarily save for their retirement.

\subsection{Estimation results using general measures for financial wealth}

Rows one and two of Table 3 show the regression results with financial wealth used as a dependent variable. The dependent variables are gross financial wealth in the first row and net financial wealth in the second row. Net financial wealth used in the second row is found by subtracting the balance of all debts but housing loans from gross financial wealth. This is because the same amount of real assets appears in the household's balance sheet when it holds housing loans, and the net value of debts for housing loans is approximately zero. $^{15,} 16$

Regardless of the dependent variable used, estimated coefficients of income uncertainty and the health dummy are not statistically significant. The results with measures of income and health uncertainty are not consistent with the Carroll and

exercise to Caggeti's one. They find that the share of precautionary wealth starts to decline a little earlier in the mid 40's than in our sample.

${ }^{15}$ In the SFAHC, respondents are asked first whether they are borrowing and then they are asked the amount of debts they owe. In order to keep the sample size large enough, we replace missing values for the amount of debts with zero even if respondents answer that they are borrowing. We apply the same principle to housing loans held by households.

${ }^{16}$ In the 1998 and 200 waves of the SFACH, respondents are asked to report the proportion of housing loans borrowed to total debts owed rather than the amount of housing loans itself. Thus, in these two waves, housing loans borrowed is obtained by multiplying the proportion by total debts owed for each household. 
Samwick's results for American households but are consistent with the results for Japanese households found by Murata (2003).

\subsection{Estimation results with self-reported financial wealth and wealth target}

Dependent variables used in rows three and four are self-reported precautionary wealth and the wealth target for a precautionary motive.

Since many households in the sample are not saving for the peace of mind motive, and hence, variables PEACE_CURRENT and PEACE_TARGET take on zero for many households, treating an observed dependent variable as a continuous variable is likely to lead to biased estimates. Thus, we estimate a Tobit model with instrumental variables assuming that the model is censored at zero for the dependent variable. We use predicted values for the independent variables from the first stage OLS regression in the maximum likelihood estimation of a second-stage Tobit model. ${ }^{17}$ Neither the estimated coefficient of income uncertainty (LVARLY) nor that of the health dummy is statistically significant when the self-reported current precautionary wealth is used as the dependent variable.

The coefficient of LVARLY is positive and statistically significant at the five percent level when the self-reported target for precautionary wealth is used. Our coefficient estimate implies that an increase in LVARLY by one percent would increase the target precautionary wealth by 0.68 percent. This means that, for instance, the self-employed, the riskiest occupation, target 28 percent more of precautionary wealth than public servants,

${ }^{17}$ We estimate a Tobit model with the two-step estimation method described in Amemiya (1979) and Smith and Blundell (1986). In the second step Tobit regression, the dependent variable is regressed on values of endogenous variables predicted by instrumental variables as well as on estimated residuals for endogenous variables obtained from the first step OLS regressions. Correction of biases in standard errors of parameter estimates resulting from the first stage OLS regressions for endogenous variables follows the way suggested by Smith and Blundell (1986). 
the safest occupation.

The coefficient of the health dummy is negative and statistically significant at the one percent level for the regression with the target as the dependent variable. The effect of the health dummy on the wealth target is large. The estimated coefficient of -0.84 means that a household with an unhealthy head targets 2.3 times as much precautionary wealth as a household with a healthy head does. As saving for unexpected medical expenditures is surveyed as a separate saving motive in the SFACH, households with an unhealthy head attempt to insure against a large income loss caused by job loss or sick leave.

Our finding is consistent with the recent findings on precautionary saving by American households. Kennickell and Lusardi (2004) find that the target for precautionary wealth surveyed in the Survey of Consumer Finances is correlated to various measures for uncertainty. Parker and Preston (2002), on the other hand find that the coefficient of the measure for income uncertainty is not statistically significant in the regression for the estimated flow of precautionary saving. Like American households, Japanese households follow the buffer stock saving behavior. What is relevant is the target for wealth not the current amount of wealth itself.

Our point estimate of the coefficient of LVARLY on the self-reported target wealth of Japanese households is about twice as large as the coefficient of the same variable on gross financial wealth for American households found by Carroll and Samwick (1997) (their point estimate is 0.368), suggesting that our use of the self-reported target is more appropriate in capturing the precautionary saving motive of households.

\subsection{Endogenous income uncertainty and use of a censored regression}

Table 4 compares the baseline result obtained using a two-stage Tobit model with 
instrumental variables for non-asset income and the measure for income uncertainty LVARLY with results obtained using the OLS, a Tobit model without instrumental variables, a two-stage Tobit model with instrumental variables for non-asset income only, and the two stage least square (2SLS).

As it turns out, the coefficient of LVARLY is always negative and statistically significant when LVARLY is not instrumented (OLS, Tobit, two-stage Tobit when instrumental variables for non-asset income only are used), suggesting that the use of instrumental variables for LVARLY is crucial in identifying the effect of income risk on the target for precautionary wealth with the opposite effect through differences in households' risk averseness.

When censoring at zero for the dependent variable is not taken into account but LVARLY is instrumented, the coefficient of LVARLY is indistinguishable from zero, suggesting that the use of a censored regression model (Tobit) is essential.

\subsection{Robustness checks}

Table 5 presents the robustness checks of our findings with the self-reported target for precautionary financial wealth as the dependent variable by estimating regressions with different samples of households.

Age and the buffer stock saving behavior: the US-Japan comparison

We change age groups included in the baseline sample and see if our findings still hold. The coefficient of LVARLY remains positive and statistically significant for the sample of households with a head aged 45 or younger. In contrast, the coefficient of LVARLY is no longer statistically significant when households with a head older than 50 are included in 
the sample. The coefficient of the health dummy remains negative but is no longer statistically significant for the sample of households with a head aged 45 or younger. The coefficient of the health dummy is not statistically significant for the sample including households with an older head. ${ }^{18}$

Our findings that income uncertainty does not influence the target for precautionary wealth suggest that our measures for income uncertainty, LVARLY and the health dummy, may not capture the risks faced by older households. Examples of such risks include the longevity risk. Though the retirement motive for saving is surveyed as a separate saving motive, respondents may choose the peace of mind motive rather than the retirement motive for vague anxieties over their longevity.

Using the US - Japan survey conducted in 1996 by the IPTP whose questionnaire is similar to the SFACH, Horioka et al (2000) find that Japanese households are found to be not strongly motivated for leaving behind bequests and that 70 percent answer "I will not make any particular efforts to leave behind a bequest but will leave to my child or children whatever assets happen to be left over." They, however, find that the proportion of households that have received bequests in the past and/or that expect to receive them in the future is 40 percent. They further show that the average bequest of households which received bequests in the past is huge $(54,110,000$ yen or 475,609 dollars (exchanged at the rate at the end of November 1996)) or 9.6 times the average annual household disposable income.)

They show that American households in contrast have a stronger willingness to leave

\footnotetext{
18 The sample of households with a head aged 40 or younger was also examined. Estimates are implausible and one of the standard errors for coefficients estimated according to Smith and Blundell (1986)'s method was an imaginary number. These may be caused by lack of an adequate sample size (882 households).
} 
behind bequests but end up leaving smaller bequests (46 percent of American households answer "I want to make efforts to leave behind a bequest" and the average bequest left is 74,756 dollars.). Accidental bequests left behind by American households are thus small.

It may be due to this difference in preference toward the longevity risk between American and Japanese households that the evidence by Carroll and Samwick (2002) and our finding in the sample including older households are not consistent with each other (Carroll and Samwick find that the coefficient of LVARLY remains statistically significant even in the sample including older households.).

\section{Excluding the self-employed}

The coefficient of LVARLY is estimated to be larger and that of the health dummy is estimated to be smaller for the sample excluding self-employed households (which includes households in agriculture or in forestry) than for the baseline sample. This may suggest that staying healthy is particularly important for the self-employed, particularly agricultural workers whose work includes more manual labor than that of salaried workers.

\section{Conclusion}

Using the Survey on the Financial Asset Choice of Households (SFACH) conducted by the Institute for Posts and Telecommunications Policy of the Ministry of Posts and Telecommunications of the Government of Japan (the present Japan Post Corporation), we analyzed the relationship between income uncertainty and precautionary wealth.

What makes the SFACH unique is the survey on the household's current financial wealth and the wealth target for at least twelve saving motives in addition to the survey on total financial assets, borrowing, and various financial and demographic variables. We 
consider saving "for peace of mind but not for specific reasons" as (self-reported) precautionary saving against income uncertainty.

Our main findings are: 1. Measures of income uncertainty have a positive influence on the self-reported target for precautionary wealth but not on precautionary wealth itself. 2 . The positive influence of income uncertainty on the self-reported target for precautionary wealth vanishes for the sample including older households with a head aged 51 or older. These findings suggest that Japanese households save against income uncertainty until around when the head is aged 50 and then save against other risks such as the longevity risk. 


\section{Reference}

Abe, Naohito and Tomoaki Yamada (2005), "The Structural Estimation of the Consumption Function: Empirical Analysis of the Buffer Stock Saving Model and Precautionary Saving," mimeo. (in Japanese)

Amemiya, Takeshi (1979), "The Estimation of a Simultaneous-Equation Tobit Model," International Economic Review, 20 (1): 169-81.

Browning, Martin and Annamaria Lusardi (1996), "Household Saving: Micro Theories and Micro Facts," Journal of Economic Literature, 34 (4): 1797-1855.

Caggetti, Marco (2003), "Wealth Accumulation over the Life-Cycle and Precautionary Saving," Journal of Business and Economic Statistics, 21 (3): 339-53.

Carroll, Christopher D. (1992), “The Buffer Stock Theory of Saving: Some Macroeconomic Evidence," Brookings Papers on Economic Activity, 1992 (2): 61-156.

Carroll, Christopher D. (1997), "Buffer Stock Saving and the Life Cycle/Permanent Income Hypothesis," Quarterly Journal of Economics, 107 (1): 1-56.

Carroll, Christopher D. and Andrew Samwick (1997), “The Nature of Precautionary Wealth," Journal of Monetary Economics 40 (1): 41-72. 
Carroll, Christopher D. and Andrew Samwick (1998), "How Important is Precautionary Saving?" Review of Economics and Statistics 80 (3): 410-419.

Carroll, Christopher D., Karen E. Dynan and Spencer D. Krane (2003), "Unemployment Risk and Precautionary Wealth: Evidence from Households' Balance Sheets," Review of Economics and Statistics, 86 (3): 586-604.

Dynan, Karen E. (1993), “How Prudent Are Consumers?” Journal of Political Economy, 101 (6): 1104-131.

Dardanoni, Valentino (1991), "Precautionary Savings under Income Uncertainty: A Cross-Section Analysis," Applied Economics, 23(1): 153-60.

Gourinchas, Pierre-Olivier and Jonathan A. Parker (2002), "Consumption over the Life Cycle," Econometrica, 70 (1): 47-89.

Hubbard, Glenn R., Jonathan Skinner, and Stephen P. Zeldes (1995), "Precautionary Saving and Social Insurance," Journal of Political Economy, 104 (2): 360-99.

Horioka, Charles Yuji and Wako Watanabe (1997), "Why Do People Save? A Micro-Analysis of Motives of Household Saving in Japan,” Economic Journal, 107 (442), 537-52.

Horioka, Charles Yuji, Hideki Fujisaki, Wako Watanabe and Takatsugu Kouno (2000). “Are 
Americans More Altruistic than the Japanese? A U.S.-Japan Comparison of Saving and Bequest Motives," International Economic Journal, 14 (1): 1-31.

Kennickell, Arthur and Annamaria Lusardi (2004), "Disentangling the Importance of the Precautionary Saving Motive,” NBER Working Paper, 10888.

Lusardi, Annamaria (1998), "On the Importance of the Precautionary Saving Motive," American Economic Review, 88 (2), Papers and Proceedings: 449-53.

Murata, Keiko (2003), "Precautionary Savings and Income Uncertainty: Evidence from Japanese Micro Data,” Monetary and Economic Studies, October: 21-52.

Palumbo, Michael G. (1999), “Uncertain Medical Expenses and Precautionary Saving Near the End of the Life Cycle," Review of Economic Studies, 66 (2): 395-421

Parker, Jonathan A. and Bruce Preston (2002), "Precautionary Saving and Consumption Fluctuations", NBER Working Paper 9196, forthcoming in American Economic Review.

Skinner, Jonathan S. (1988), "Risky Income, Life Cycle Consumption, and Precautionary Savings," Journal of Monetary Economics, 22 (2): 237-55.

Smith, Richard J. and Richard W. Blundell (1986), “An Exogeneity Test for a Simultaneous Equation Tobit Model with an Application to Labor Supply," Econometrica, 54 (3): 679-86. 
Zhou, Yanfei (2003), "Precautionary Saving and Earnings Uncertainty in Japan," Journal of the Japanese and International Economies, 17 (2): 192-212. 
Table 1 The measure for uncertainty of non-asset income by occupation

\begin{tabular}{lrr}
\hline Occupation & $\begin{array}{c}\text { The logarithm of the } \\
\text { variance of the } \\
\text { logarithm }\end{array}$ & The standard error \\
\hline Private entity, less than 30 employees & 0.5120 & 313.2 \\
Private entity, 30 or more but less than 500 employees & 0.4771 & 404.6 \\
Private entity, more than 500 employees & 0.4959 & 398.9 \\
Public service & 0.4365 & 415.0 \\
Self-employment & 0.7146 & 826.5 \\
\hline $\mathrm{N}$ & 3903 & 3903 \\
\hline
\end{tabular}

A unit of non-asset income is 10,000 yen

Table 2. Descriptive statistics

Continuous variables

\begin{tabular}{lrrrrr}
\hline & N & Mean & \multicolumn{1}{c}{ Std } & MIN & \multicolumn{1}{c}{ MAX } \\
\hline The current wealth for the PM motive & 2983 & 170.2 & 479.2 & 0 & 8100 \\
The wealth target for the PM motive & 2825 & 242.6 & 771.0 & 0 & 12000 \\
Gross financial wealth & 3351 & 1120.7 & 1369.7 & 1 & 21100 \\
Net financial wealth & 3351 & 993.3 & 1555.3 & -26013 & 21100 \\
After tax non-asset income & 3903 & 765.2 & 439.8 & 4 & 7700 \\
LVARLY & 2983 & -1.529 & 0.5485 & -2.946 & 0.080 \\
Age of the household head in the survey year & 3903 & 45.5 & 8.27 & 30 & 59 \\
Age of the household head in 1990 & 3903 & 38.6 & 8.7 & 20 & 55 \\
Number of children & 3903 & 1.70 & 0.97 & 0 & 7 \\
\hline
\end{tabular}

Note:

1. Amounts are in 10,000 yen.

2. In calculating summary statistics for the current wealth for the peace of mind (PM) motive and the wealth target for the peace of mind motive, respondents who reported they have savings for the peace of mind motive but do not give the amount are excluded.

3. LVARLY is the logarithm of the variance of the logarithm of non-asset household income. 
Binary variables

\begin{tabular}{|c|c|c|c|}
\hline \multirow{2}{*}{$\overline{\text { Region }}$} & \multirow[b]{2}{*}{ Hokkaido and Tohoku } & \multicolumn{2}{|c|}{ Frequency Proportion } \\
\hline & & 444 & 11.35 \\
\hline & Kanto & 1260 & 32.28 \\
\hline & Chubu and Kinki & 1267 & 32.46 \\
\hline & Chugoku and Shikoku & 424 & 10.86 \\
\hline & Kyushu & 509 & 13.04 \\
\hline & Total & 3903 & \\
\hline \multirow[t]{7}{*}{ City size } & Tokyo 23 boroughs & 314 & 8.05 \\
\hline & 11 large cities & 669 & 17.14 \\
\hline & Cities of population over 150,000 & 1195 & 30.62 \\
\hline & Cities of population over 50,000 & 726 & 18.60 \\
\hline & Cities of population below 50,000 & 244 & 6.25 \\
\hline & Counties (rural) & 755 & 19.34 \\
\hline & Total & 3903 & \\
\hline \multirow[t]{6}{*}{ Occupation of the head } & Private entities, less than 30 employees & 540 & 13.84 \\
\hline & Private entities, less than 500 employees & 1031 & 26.42 \\
\hline & Private entities, 500 or more employees & 1052 & 26.95 \\
\hline & Public service & 479 & 12.27 \\
\hline & Agriculture, forestry, and self-employment & 801 & 20.52 \\
\hline & Total & 3903 & \\
\hline \multicolumn{2}{|c|}{ Educational attainment Junior high school } & 505 & 12.94 \\
\hline \multirow[t]{3}{*}{ of the head } & High school & 1897 & 48.60 \\
\hline & Advanced education & 1501 & 38.46 \\
\hline & Total & 3903 & \\
\hline Health condition of & Healthy & 3729 & 95.54 \\
\hline \multirow[t]{2}{*}{ the household head } & Sick & 174 & 4.46 \\
\hline & Total & 3903 & \\
\hline
\end{tabular}


Table 3. Estimation results

\begin{tabular}{|c|c|c|c|c|}
\hline & \multicolumn{4}{|c|}{ Dependent variable } \\
\hline & \multicolumn{2}{|c|}{ Financial wealth } & \multicolumn{2}{|c|}{ Peace of mind motive } \\
\hline & Gross & Net & $\begin{array}{l}\text { Current } \\
\text { wealth }\end{array}$ & Target wealth \\
\hline $\begin{array}{l}\text { LNINCOME (log of } \\
\text { non-asset income) }\end{array}$ & $\begin{aligned} 1.568^{* * *} \\
(0.188)\end{aligned}$ & $\begin{array}{l}2.482^{* * *} \\
(0.533)\end{array}$ & $\begin{array}{l}4.552^{* * *} \\
(0.291)\end{array}$ & $\begin{array}{l}5.150^{* * *} \\
(0.327)\end{array}$ \\
\hline LNVARLY & $\begin{array}{l}-0.220 \\
(0.168)\end{array}$ & $\begin{array}{l}-0.100 \\
(0.476)\end{array}$ & $\begin{array}{l}0.291 \\
(0.249)\end{array}$ & $\begin{array}{l}0.683^{* *} \\
(0.268)\end{array}$ \\
\hline Health dummy & $\begin{array}{l}0.051 \\
(0.138)\end{array}$ & $\begin{array}{l}-0.021 \\
(0.389)\end{array}$ & $\begin{array}{l}-0.253 \\
(0.203)\end{array}$ & $\begin{array}{r}-0.839^{* * *} \\
(0.245)\end{array}$ \\
\hline Head age & $\begin{array}{r}-2.179^{* * *} \\
(0.384)\end{array}$ & $\begin{array}{r}-3.994^{* * *} \\
(1.087)\end{array}$ & $\begin{array}{r}-4.035^{* * *} \\
(0.585)\end{array}$ & $\begin{array}{r}-3.092^{* * *} \\
(0.668)\end{array}$ \\
\hline Head age squared & $\begin{array}{r}-0.0032^{* * *} \\
(0.0008)\end{array}$ & $\begin{array}{r}-0.0048^{* *} \\
(0.0022)\end{array}$ & $\begin{array}{l}0.0053^{* * *} \\
(0.0012)\end{array}$ & $\begin{array}{r}0.0101^{* * *} \\
(0.0014)\end{array}$ \\
\hline Head age in 1990 & $\begin{array}{r}2.447^{* * *} \\
(0.432)\end{array}$ & $\begin{array}{r}4.376^{* * *} \\
(1.221)\end{array}$ & $\begin{array}{r}3.430^{* * *} \\
(0.655)\end{array}$ & $\begin{array}{r}2.021^{* * *} \\
(0.749)\end{array}$ \\
\hline The number of children & $\begin{array}{l}0.009 \\
(0.026)\end{array}$ & $\begin{array}{r}-0.132^{*} \\
(0.072)\end{array}$ & $\begin{array}{r}-0.136^{* * *} \\
(0.039)\end{array}$ & $\begin{array}{r}-0.274^{* * *} \\
(0.046)\end{array}$ \\
\hline Year dummy for 1996 & $\begin{array}{r}4.655^{* * *} \\
(0.840)\end{array}$ & $\begin{array}{l}8.434^{* * *} \\
(2.377)\end{array}$ & $\begin{array}{r}8.174^{* * *} \\
(1.271)\end{array}$ & $\begin{array}{r}5.820^{* * *} \\
(1.453)\end{array}$ \\
\hline Year dummy for 1998 & $\begin{array}{r}9.932^{* * *} \\
(1.742)\end{array}$ & $\begin{array}{r}17.456^{* * *} \\
\quad(4.927)\end{array}$ & $\begin{array}{r}14.990^{* * *} \\
(2.641)\end{array}$ & $\begin{array}{r}10.561^{* * *} \\
(3.018)\end{array}$ \\
\hline Year dummy for 2000 & $\begin{array}{r}14.838^{* * *} \\
(2.599)\end{array}$ & $\begin{array}{r}25.986^{* * *} \\
\quad(7.353)\end{array}$ & $\begin{array}{r}21.032^{* * *} \\
(3.942)\end{array}$ & $\begin{array}{r}14.321^{* * *} \\
(4.507)\end{array}$ \\
\hline $\begin{array}{l}\text { The predicted residual } \\
\text { for LNINCOME }\end{array}$ & & & $\begin{array}{r}1.174^{* * *} \\
(0.290)\end{array}$ & $\begin{array}{r}1.507^{* * *} \\
(0.327)\end{array}$ \\
\hline $\begin{array}{l}\text { The predicted residual } \\
\text { for LVARLY }\end{array}$ & & & $\begin{array}{r}-0.562^{* *} \\
(0.249)\end{array}$ & $\begin{array}{r}-0.960^{* * * *} \\
(0.268) \\
\end{array}$ \\
\hline $\mathrm{N}$ & 2267 & 2267 & 2014 & 1902 \\
\hline
\end{tabular}

Note

$1 . * * *$ and $* * *$ show that a coefficient is statistically significant at $10 \%, 5 \%$ and $1 \%$ respectively.

2. LNVARLY is thea logarithm of the variance of the logarithm of non-asset household income.

3. In the text, current wealth for the peace of mind motive and the target wealth for the peace of mind motive are sometimes abbreviated as PEACE_CURRENT and PEACE_TARGET respectively. 
Table 4. Results of alternative econometric models for the target precautionary wealth

\begin{tabular}{|c|c|c|c|c|c|}
\hline & $\begin{array}{c}\text { Two-step Tobit } \\
\text { (baseline from } \\
\text { Table 3) }\end{array}$ & OLS & Tobit & $\begin{array}{l}\text { Two-step Tobit, } \\
\text { LNVARLY is } \\
\text { exogenous }\end{array}$ & 2SLS \\
\hline logarithm of non-asset & $5.150^{* * *}$ & $0.617^{* * *}$ & $1.777^{* * *}$ & $5.118^{* * *}$ & $1.747^{* * * *}$ \\
\hline income & $(0.327)$ & $(0.138)$ & $(0.425)$ & $(0.292)$ & $(0.521)$ \\
\hline LVARLY & $\begin{array}{c}0.683^{* *} \\
(0.268)\end{array}$ & $\begin{array}{r}-0.261^{* *} \\
(0.133)\end{array}$ & $\begin{array}{r}-0.836^{* *} \\
(0.393)\end{array}$ & $\begin{array}{r}-0.494^{* * *} \\
(0.076)\end{array}$ & $\begin{array}{l}0.066 \\
(0.427)\end{array}$ \\
\hline Health dummy & $\begin{array}{r}-0.839^{* * *} \\
(0.245)\end{array}$ & $\begin{array}{r}-0.171 \\
(0.382)\end{array}$ & $\begin{array}{r}-0.598 \\
(1.098)\end{array}$ & $\begin{array}{r}-0.748^{* * *} \\
(0.219)\end{array}$ & $\begin{array}{r}-0.231 \\
\quad(0.390)\end{array}$ \\
\hline Head age & $\begin{array}{r}-3.092^{* * *} \\
(0.668)\end{array}$ & $\begin{array}{l}0.918 \\
(0.722)\end{array}$ & $\begin{array}{l}0.119 \\
(2.285)\end{array}$ & $\begin{array}{r}-4.225^{* * *} \\
(0.572)\end{array}$ & $\begin{array}{r}-0.361 \\
\quad(1.066)\end{array}$ \\
\hline Head age squared & $\begin{array}{c}0.0101^{* * *} \\
(0.0014)\end{array}$ & $\begin{array}{l}0.0035 \\
(0.0021)\end{array}$ & $\begin{array}{l}0.0086 \\
(0.0060)\end{array}$ & $\begin{array}{l}0.0087^{* * *} \\
(0.00120)\end{array}$ & $\begin{array}{l}0.0037^{*} \\
(0.0022)\end{array}$ \\
\hline Head age in 1990 & $\begin{array}{r}2.021^{* * *} \\
(0.749)\end{array}$ & $\begin{array}{r}-1.249 \\
(0.885)\end{array}$ & $\begin{array}{r}-0.960 \\
\quad(2.554)\end{array}$ & $\begin{array}{r}3.291^{* * *} \\
(0.640)\end{array}$ & $\begin{array}{r}-0.021 \\
(3.009)\end{array}$ \\
\hline The number of children & $\begin{array}{c}-0.274^{* * *} \\
(0.046)\end{array}$ & $\begin{array}{l}-0.081 \\
(0.071)\end{array}$ & $\begin{array}{r}-0.217 \\
(0.209)\end{array}$ & $\begin{array}{r}-0.268^{* * *} \\
(0.041)\end{array}$ & $\begin{array}{r}-0.274 \\
\quad(1.194)\end{array}$ \\
\hline Year dummy for 1996 & $\begin{array}{c}5.820^{* * *} \\
(1.453)\end{array}$ & $\begin{array}{l}-1.569 \\
(1.7847)\end{array}$ & $\begin{array}{l}0.831 \\
(5.1284)\end{array}$ & $\begin{array}{r}8.341^{* * *} \\
(1.238)\end{array}$ & $\begin{array}{l}0.556 \\
\quad(2.316)\end{array}$ \\
\hline Year dummy for 1998 & $\begin{array}{r}10.561^{* * *} \\
(3.018)\end{array}$ & $\begin{array}{r}-4.381 \\
(3.557)\end{array}$ & $\begin{array}{l}-1.7040 \\
(10.227)\end{array}$ & $\begin{array}{r}15.623^{* * *} \\
(2.585)\end{array}$ & $\begin{array}{l}0.639 \\
\quad(4.813)\end{array}$ \\
\hline Year dummy for 2000 & $\begin{array}{r}14.321^{* * *} \\
(4.507)\end{array}$ & $\begin{array}{r}-6.864 \\
(5.327)\end{array}$ & $\begin{array}{l}-3.607 \\
(15.317)\end{array}$ & $\begin{array}{r}21.967^{* * *} \\
(3.854)\end{array}$ & $\begin{array}{l}0.519 \\
(18.117)\end{array}$ \\
\hline $\begin{array}{l}\text { The predicted residual } \\
\text { for LNINCOME }\end{array}$ & $\begin{array}{l}1.507^{* * *} \\
(0.327)\end{array}$ & & & $\begin{array}{r}1.505^{* * *} \\
(0.292)\end{array}$ & \\
\hline $\begin{array}{l}\text { The predicted residual } \\
\text { for LVARLY }\end{array}$ & $\begin{array}{r}-0.960^{* * *} \\
(0.268) \\
\end{array}$ & & & & \\
\hline $\mathrm{N}$ & 1902 & 1902 & 1902 & 1902 & 1902 \\
\hline
\end{tabular}

Note

1. * $* *$ and $* * *$ show that a coefficient is statistically significant at $10 \%, 5 \%$ and $1 \%$ respectively. 2. LNVARLY is the logarithm of the variance of the logarithm of non-asset household income. 
Table 5. Robustness checks

\begin{tabular}{|c|c|c|c|c|c|}
\hline & 45 or younger & $\begin{array}{c}50 \text { or younger } \\
\text { (baseline from } \\
\text { Table } 3 \text { ) }\end{array}$ & 55 or younger & 59 or younger & $\begin{array}{c}\text { Exclude } \\
\text { agriculture, forestry } \\
\text { and } \\
\text { self-employment } \\
\end{array}$ \\
\hline LVARLY & $\begin{array}{r}0.803^{* * *} \\
(0.407)\end{array}$ & $\begin{array}{l}0.683^{* *} \\
(0.268)\end{array}$ & $\begin{array}{l}1.090 \\
(0.868)\end{array}$ & $\begin{array}{l}0.054 \\
(0.645)\end{array}$ & $\begin{array}{c}0.956^{* * *} \\
(0.258)\end{array}$ \\
\hline Health dummy & $\begin{array}{r}-0.233 \\
(0.423) \\
\end{array}$ & $\begin{array}{r}-0.839^{* * *} \\
(0.245) \\
\end{array}$ & $\begin{array}{l}0.206 \\
(0.248) \\
\end{array}$ & $\begin{array}{r}-0.054 \\
(0.178) \\
\end{array}$ & $\begin{array}{r}-0.563^{* *} \\
(0.248) \\
\end{array}$ \\
\hline $\mathrm{N}$ & 1363 & 1902 & 2403 & 2817 & 1597 \\
\hline
\end{tabular}

\section{Note}

1. * ** and *** show that a coefficient is statistically significant at $10 \%, 5 \%$ and $1 \%$ respectively.

2. LVARLY is the logarithm of the variance of the logarithm of non-asset household income. 
Figure 1-1 Age profile of gross financial wealth

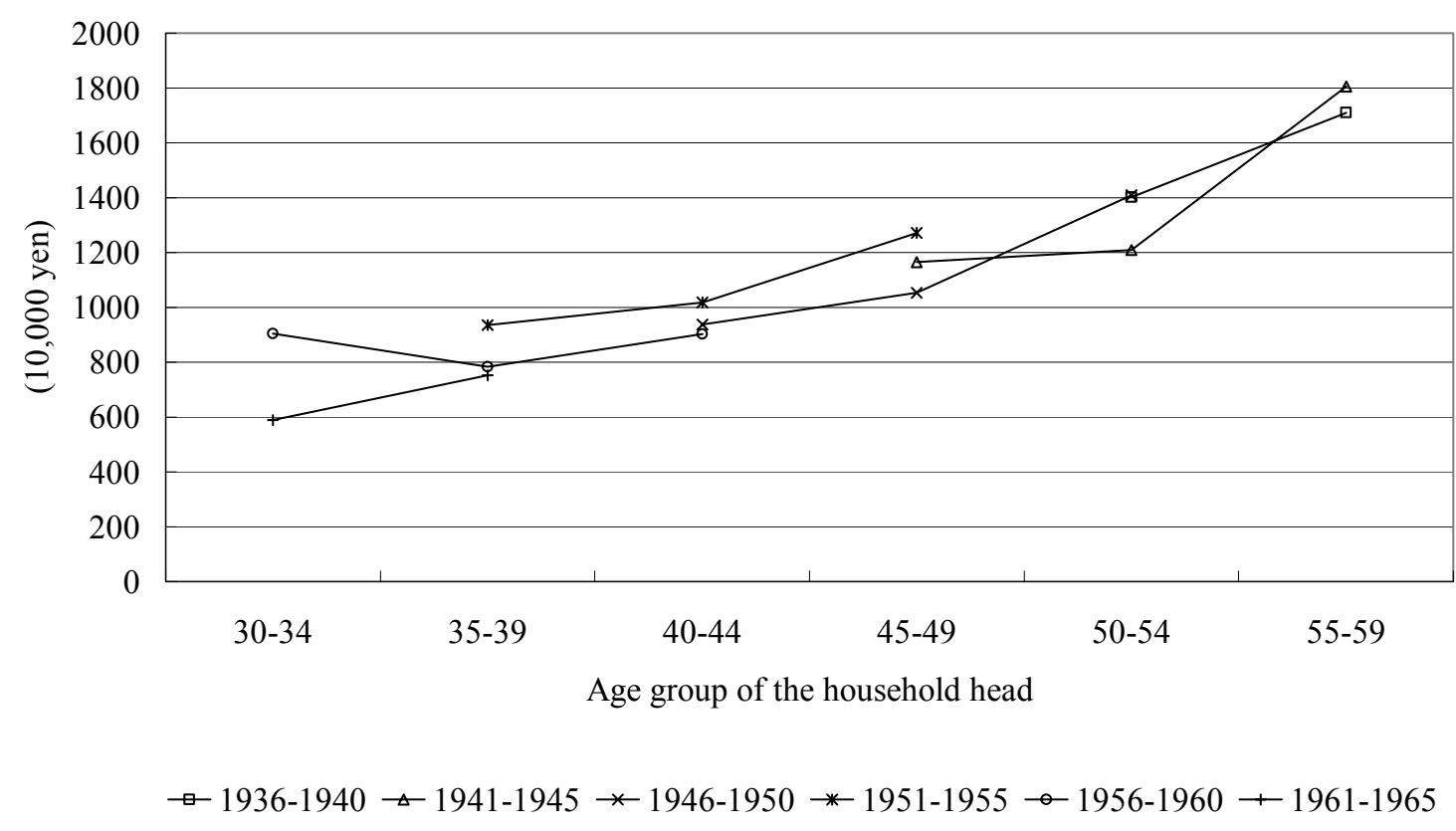

Note: Each curve tracks households in the same cohort.

Figure 1-2 Age profile of net financial wealth

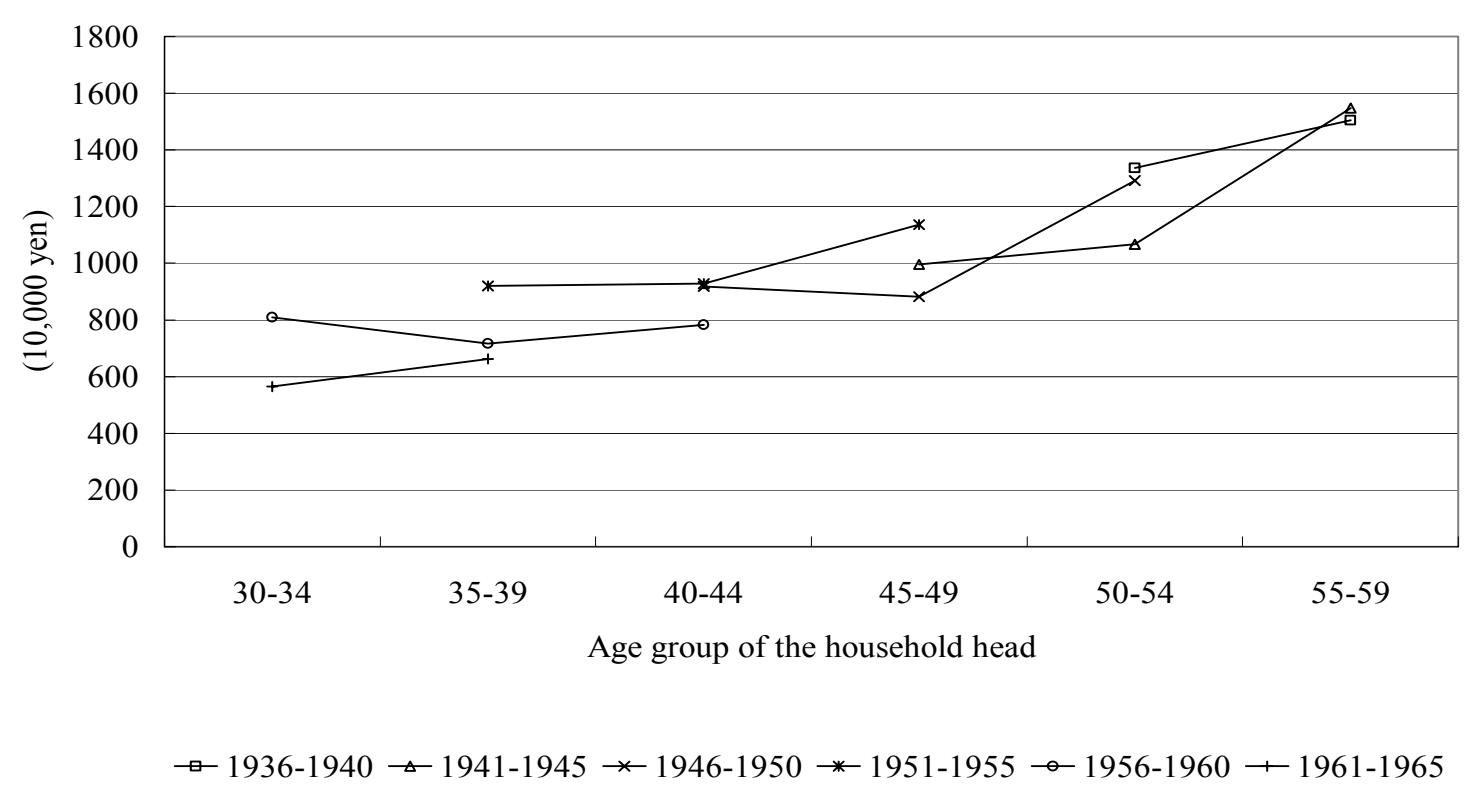

Note: Each curve tracks households in the same cohort. 
Figure 1-3 Age profile of financial wealth for the peace of mind motive

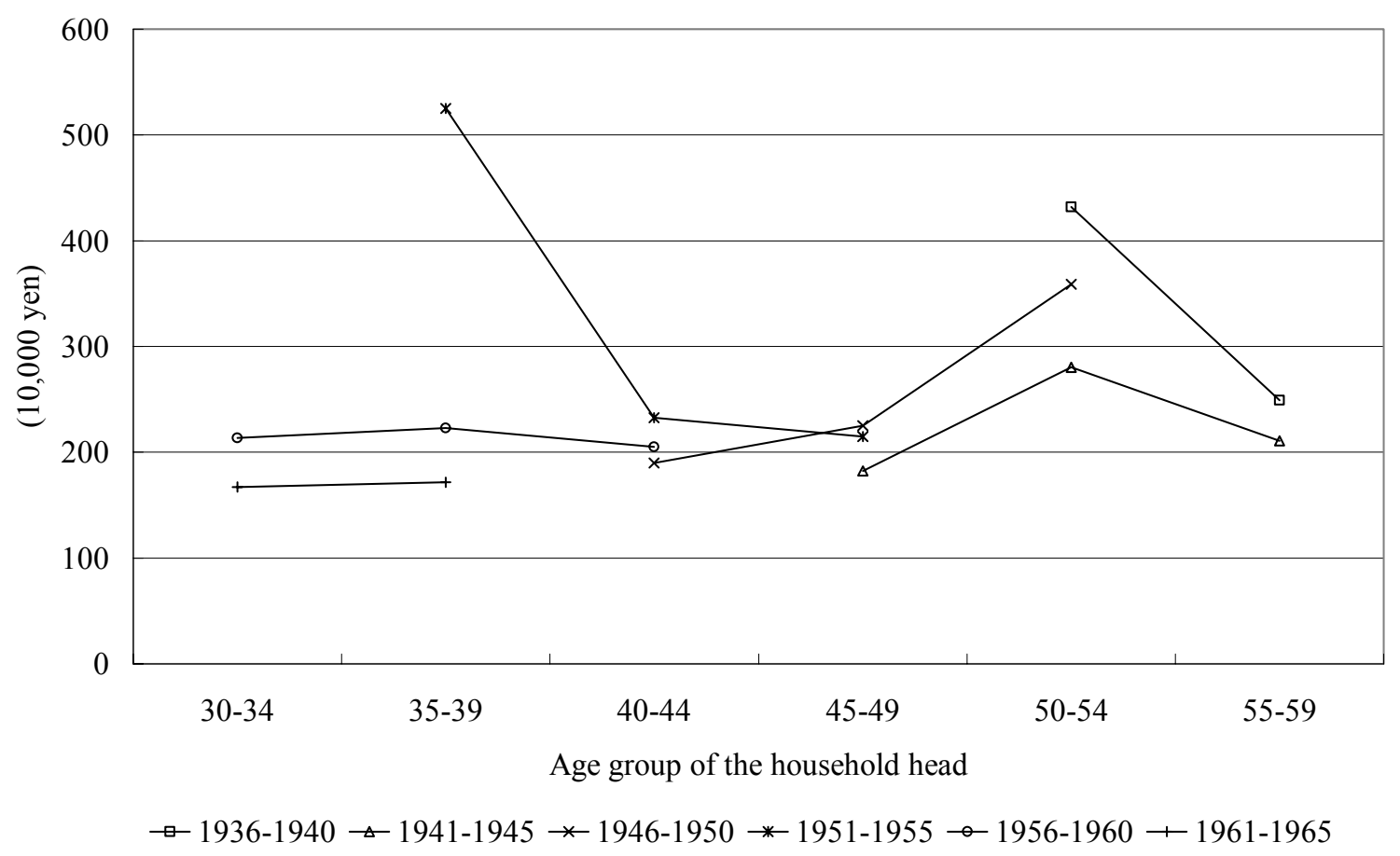

Note:

1. Each colored curve tracks households in the same cohort.

2. Households that save for the peace of mind motive but do not report current financial wealth accumulated for the peace of mind motive are assumed to have the average for households who report current financial wealth for the peace of mind motive. 
Figure 1-4 Age profile of the share of financial wealth for the peace of mind motive

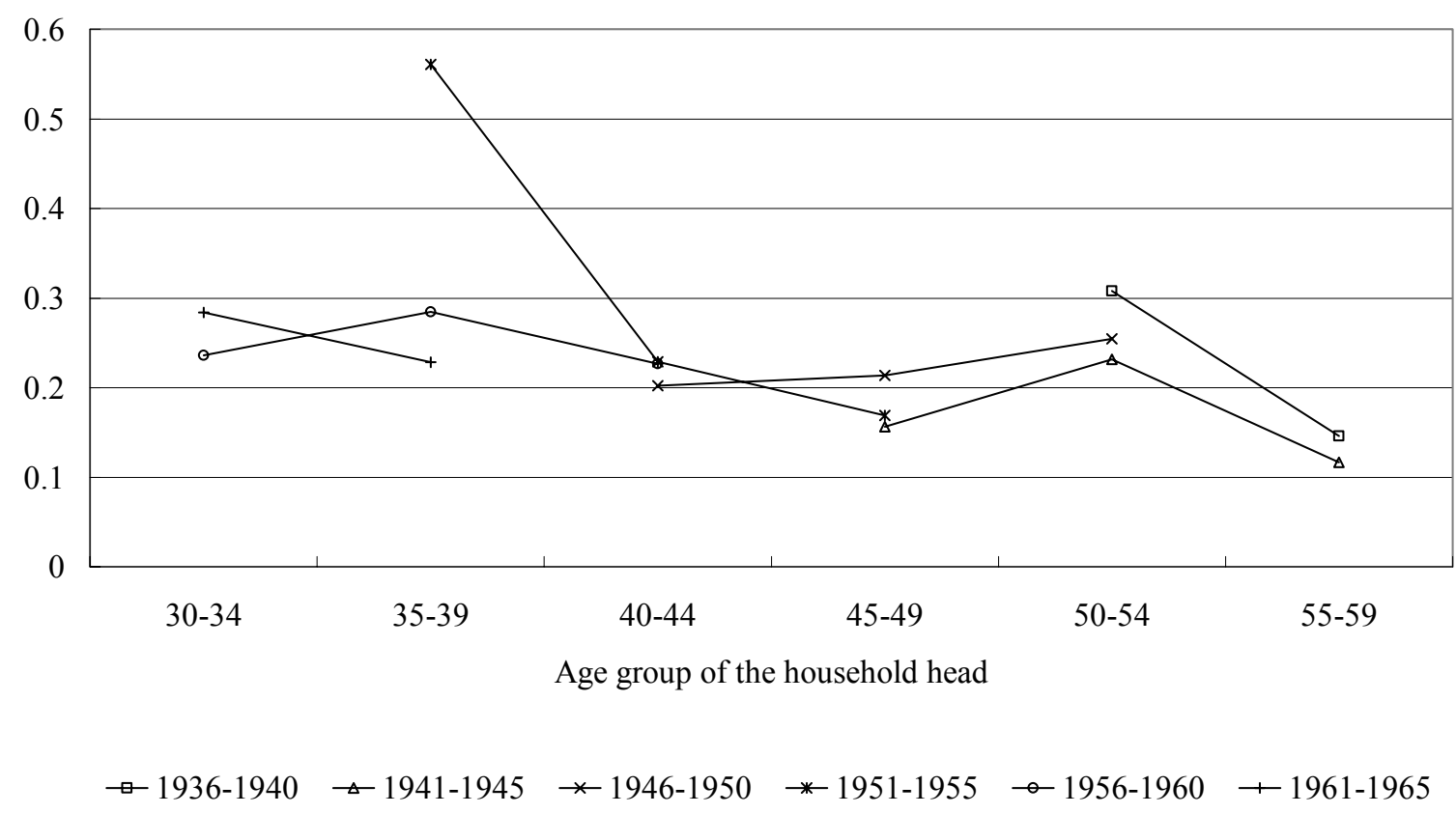

Note:

1. Each colored curve tracks households in the same cohort.

2. Households that save for the peace of mind motive but do not report current financial wealth accumulated for the peace of mind motive are assumed to have the average for households who report current financial wealth for the peace of mind motive.

3. The share is taken against gross financial wealth. 